\title{
Profession, organisation, kollegialitet och ansvar
}

\author{
LENNART G SVENSSON
}

Ansvar är en vanlig term i lagar och etiska regler. Det är också en vanlig fräga i offentlig debatt. Artikeln presenterar ett antal begrepp för kontroll och styrning av professionellt arbete och redogör för olika typer av ansvar. Artikeln tar därmed upp ett välkänt tema i professionsstudier, nämligen relationen mellan byråkrati och profession. Politiska samhällsuppdrag anger delvis den etik som professionella byråkratier äger och utövar på anställda. Men ansvaret för arbetet vilar först och främst på den professionella och kollegiala organisationen. Politiska beslut, byräkratiska regler, professionell kunskap och etik samt allmänhetens efterfrågan på marknader, utgör fem grunder för att ange goda skäl för yrkesutövande och samtidigt för att utkräva ansvar. Men organisationsförändringar har förskjutit tyngdpunkten mellan dessa legitimitets- och styrformer, vilket också är ett aktuellt tema i dagens offentliga debatt.

\section{Inledning ${ }^{1}$}

Syftet med denna artikel är att analysera olika former av kontroll, styrning, legitimitet

Lennart G Svensson är professor emeritus vid Sociologiska institutionen, Göteborgs universitet och fortfarande verksam i studier av professioner och andra yrken. och ansvar med exempel från tre verksamheter, sjukvård, skola och socialtjänst i offentlig sektor. Särskilt uppmärksammas motsättningar och likheter mellan kollegialitet och

1 En stor del av denna artikel är hämtad från Svensson, L. G. \& Karlsson, A. (2008) "Profesjoner, kontroll och ansvar" i Molander \& Terum red. Den finns också på engelska i Svensson, L. G. \& Evetts, J. (red. 2010) 
byråkrati samt yrkesprofessionalism och organisatorisk professionalism, dvs. professionalism genom kollegial auktoritet i professionella yrkesförbund och rationellt-legal auktoritet i byråkratiska arbetsorganisationer (Evetts 2006; Liljegren \& Parding 2010; Muzio m. fl. 2011). Diskussionen gäller hur kollegialitet och yrkesprofessionalism är kopplad till och invävd i arbetsorganisationernas styrning och praktiker, och hur ansvar därmed formuleras och utkrävs. Den genomgående frågan är: hur bryts professionell ansvar mot andra former av ansvar? Frågan anknyter till den klassiska diskussionen om motsättningar mellan profession och byråkrati som åter aktualiseras starkt i samtida samhällsförändringar, där kollegialiteten som organisationsform utmanas. Det anknyter därmed också till aktuella frågor om ansvar och till den samtida trenden att peka ut ansvar och ansvariga.

Ett sätt att ange skillnaderna mellan professioner och andra yrken är följande: professioner förvaltar en viss typ av kunskap $i$ en kollegial organisationsform med politisk legitimitet att genomföra ett visst samhällsuppdrag. Kunskapen är vetenskapsbaserad och bestämd genom vissa krav för examina och eventuella legitimationer. I den kollegiala formen är yrkesutövarna organiserade på grundval av gemensam kunskap och etik hos medlemmar i en professionell sammanslutning. Den kollegiala organisationsformen är det professionella arbetets grund och skiljer sig från byråkratiska regler och efterfrågan på marknader, där chefer respektive kunder kontrollerar arbetet snarare än de professionella yrkesutövarna (Freidson 2001:12). Det politiskt beslutade samhällsuppdraget anger delvis den etik som sammanslutningarna äger och utövar över medlemmarna. Men ansvaret för arbetet vilar först och främst på den professionella och kollegiala organisationen. Kunskaper, etik, beslut, regler och efterfrågan utgör således fem olika grunder för att ange goda skäl för yrkesutövandet och samtidigt för att utkräva ansvar. Konflikter mellan dessa är vanliga i professionellt arbete bland annat på grund av professionellas anspråk på självständighet och kollegialitet.

Historiskt har professionella sammanslutningar varit mera framträdande i den anglosaxiska världen, medan den kollegiala organisationsformen varit mera invävd i arbetsorganisationernas byråkratiska former i den kontinentala och skandinaviska världen. Från vår horisont kan därför påstådda motsättningar mellan profession och byråkrati i anglosaxiska professionsstudier te sig överdrivna. Skillnaderna har dessutom minskat genom att s.k. nytt ledarskap och marknadsliknande former (New Public Management) har införts i båda världarna. New Public Management baseras på rationell-legal och hierarkisk auktoritet (regler) till skillnad från kollegial auktoritet (kunskap och etik) praktiserad av yrkesutövarna. Den strävar efter standardiserade procedurer till skillnad från kollegial och diskretionär kontroll av arbetet. Målsättningar och resultat- och ansvarsutkrävande förläggs utanför sammanslutningarnas kontroll och professionsetik. Det har resulterat i nya former av professionalism med starkare betoning på såväl individuell självdisciplinering $i$ arbetet som det professionella arbetets resultat $i$ efterhand, vilket inneburit betydande brytning mot kollegial organisering. 
Professionella yrken skiljer sig också från andra yrken genom att det ofta handlar om komplicerade bedömningar $i$ enskilda fall med hjälp av generella kunskaper, dvs. utövande av diskretion är utbrett. Tjänster med moraliska implikationer utförda ofta i direkta möten med klienter är typiska för s.k. humantjänsteorganisationer till skillnad från varuproducerande organisationer, vilket gör arbetet svårt att övervaka och kontrollera (Hasenfeld 1983; Larsson \& Morén 1988; Svensson 2008). Osäkerhet och självständighet samtidigt med samhällsuppdrag av stor och ofta avgörande betydelse för enskilda medborgare, skapar dock ett väsentligt dilemma för samhället i stort, ur rättslig och demokratisk synvinkel och för ledningar i arbetsorganisationer ur effektivitetssynpunkt. För statliga institutioner handlar det om rättssäkerhet och likhet, när medborgarna har rätt till vissa tjänster och nyttigheter och kan ställa krav på att behandlas lika. För arbetsorganisationers ledningar handlar det snarare om kontroll av resultat i termer av ekonomisk effektivitet och kvalitet. I det första fallet har vi att göra med den demokratiska rättstatens "svarta hål", i det andra med "organisationers blinda fläck" (Mintzberg 1983:190; Johansson 1992:kap. 6; Eriksen 2001; Eriksen och Molander 2008). Dessa dilemman ställer i sin tur krav på kontroll av professionellt arbete.

\section{Kollegialitet, kontroll, styrning, legitimitet och ansvar}

Alla professioner är på något sätt knutna till organisationer. Det är organisationer för utbildning, särskilda professionella organisationer eller förbund för respektive yrke samt framförallt arbetsorganisationer, där själva yrkesutövandet görs möjligt och inom vilka den professionella kollegiala formen praktiseras. Professioner är på det sättet starkt organisations- och kontextberoende, vilket ofta är underskattat i studier av professionellt arbete. Det är också i och genom dessa kontexter - inbegripet relationen till klienter - som kontrollen av yrkesutövningen sker och ansvaret utkrävs. Professionellt arbete under kollegiala former kan knappast förekomma fristående utan sker $\mathrm{i}$ arbetsorganisationer med visst ledarskap och på marknader med viss efterfrågan (Freidson 2001). Även privatpraktiserande professionella är underställda vissa förvaltningsregler under tillsyn. Motsättningar mellan profession och organisation överdrivs ofta, trots att flera klassiska studier som citerats frekvent, visat hur professionellt arbete behöver byråkratiska arbetsorganisationer (Wilensky 1964; Hall 1968; Lipsky 1980; Hasenfeld 1983). Professionella är vanligen anställda i professionella byråkratiska arbetsorganisationer där de använder dessa organisationers resurser i sitt dagliga arbete och i sina långsiktiga yrkeskarriärer. Där får de också tillgång till klienter och metoder och teknologier för diagnoser och behandlingar (Bourgeault m. fl. 2011). Å andra sidan förser professionella sina arbetsorganisationer med klienter, med externa nätverk och framförallt med expertis och kompetens. 


\section{Kollegialitet}

Termen kollega står för yrkes- och arbetskamrat (tidigare ämbetsbroder eller medlem av skrået), vanligen på jämförbar nivå och inkluderar ofta ömsesidighet och sammanhållning. Tidigare har det huvudsakligen rört yrken med längre utbildning och ofta med professionella anspråk. Numera har termen spridits också till andra yrken - kanske i takt med att termen professionalism brett ut sig. Kollegialitet i allmänhet betyder sammanhållning. Kollegial organisationsform utmärks av likhet och samarbete mellan kollegor, ibland med olika formell kompetens ofta baserad på legitimation eller auktorisation samt en inre självkontroll kollegor emellan (Waters, 1989; Lazega, 2001; Grimen, 2008). Kollegial beslutsmetod är beslut som fattas gemensamt efter att var och en motiverat sin mening och finns reglerad i lagtexter angående omröstningar. Motsatsen är enrådighetsprincipen, där chefen ensam fattar beslut. Kollegial beslutsmetod har stor utbredning i både formella och informella samarbetsformer i många verksamheter. ${ }^{2}$ Sjukhusens vårdlag tillämpar ofta denna metod, även om en behandlingsansvarig har det yttersta ansvaret. I skolans värld har begreppen kollega och kollegial funnits länge, men fått en renässans i kritiken av det ofta starkt individuella läraryrket - ibland dock som uppifrån påtvingad kollegialitet med t.ex. arbetslag (Hargreaves

2 Om utvärderingar förekommer som ny svensk term kollegebedömning i betydelsen bedömning mellan kollegor inom en profession (Vedung 2011:115).
1994: kap. 9). I socialt arbete är arbetsteam- och beslutsgrupper också vanliga ibland som flerprofessionella grupper.

\section{Kontroll, styrning och ansvar}

Med kontroll avses här bestämning eller påverkan av yrkesutövares handlingar och handlingsutrymme. Det är ett allmännare begrepp än styrning som avser avsiktlig kontroll eller påverkan. Styrning kan vara formellt beslutad eller informellt institutionaliserad och därmed sedan länge tagen för given så att avsiktligheten gått förlorad och att den uppfattas som traditioner, vanor eller rutiner snarare än som vare sig kontroll eller styrning. Den kan vidare vara kodifierad, dvs. upptecknad som normer, lagar, föreskrifter, scheman, manualer, kontrakt och andra styrdokument, eller icke kodifierad, buren av aktörer som tradering eller tysta överenskommelser. Kontroll i arbetsorganisationer kan förekomma på förhand som en kortare eller längre yrkesutbildning tillsammans med socialisation in i både yrke och arbetsplats (ibland i kombination med medlemskap i professionell medlemsförening eller fackförbund) som därmed standardiserar arbetskraften. ${ }^{3}$ Detta är mest typiskt för professionella yrken med längre utbildning i särskilda institutioner och medlemskap i professionella organisationer, varifrån den kollegiala kontrollen baserad på kunskap och etik utgår. Kollegial självkontroll komplet-

3 I organisationslitteratur ofta kallad Human Resource Management resp. kulturell kontroll (Scott 2003:309ff; Child 2005:kap. 5). 
teras av yrkesutövares egen självreglering med tillfredsställelse eller dåligt samvete som sanktion. Kontrollen kan vidare förekomma som överordnades övervakning, och även som klienters kontroll samtidigt med att arbetet utförs; eller som kodifierade byråkratiska regler och föreskrifter eller inbyggda tekniska system med ständiga digitala kontroller som en standardisering av arbetsprocessen. Slutligen kan kontrollen förekomma i efterhand som uppföljande beräkningar av resultat och utvärderingar av utfört arbete i kombination med olika former av ansvarsutkrävande.

Kontrollen av professioner har i mindre utsträckning skett samtidigt i form av aktiv ordergivning och övervakning och mera av kontroll på förhand i form av passiva regler och tekniker, rutiner och hierarkier samt kunskaper och färdigheter jämte övertygande socialisation från yrkesutbildningar och yrkespraktiker. Under senare decennier har det emellertid skett betydande förändringar vad gäller former för kontroll av professionellt arbete med framförallt större betoning på kontroll och ansvarsutkrävande i efterhand av utfört arbete. (Det torde vara en förklaring till trenden att peka ut ansvar och ansvariga, där ansvariga tar sitt ansvar i efterhand genom att avgå eller åtminstone med löfte om "att se över rutinerna" som det ofta heter.) På motsvarande sätt kan ansvar för arbetet i princip utkrävas på förhand som en slags garanti av dess kvalitet genom viss förberedande utbildning och praktik, och att utförandet överlämnas med förtroende till enskilda yrkesutövares diskretion. Ansvaret kan utkrävas under tiden arbetet pågår genom inbyggda kontroller med manualer och liknande jämte kollegial över- vakning och inre självkontroll. Ansvaret kan utkrävas i efterhand som utvärderingar av resultat. Ansvar kräver självständighet eller diskretion i yrkesutövningen. Alltså, ju mer direktstyrt arbetet är, tekniskt eller direktövervakat, och ju fler regler utan marginal för bedömningar och avgöranden från fall till fall, desto mindre ansvar kan utkrävas av yrkesutövarna. Professionellt arbete är oftast mera självständigt eller diskretionärt samtidigt som det utgår från ett samhällsuppdrag. Därmed kräver det etiskt grundade bedömningar och rättfärdiganden eller legitimeringar som ger större ansvar. Legitimeringarna kan i princip vara baserade på förvaltningsregler i kombination med yrkesetiska regler och värden som man har att lyda eller rätta sig efter, eller - som det typiska i professionellt arbete - kunskap och beprövad erfarenhet i ett kollegialt sammanhang ofta med professionsetisk hänsyn. Till detta kommer efterfrågan på en marknad. Beslut om åtgärder i professionellt arbete utgör ofta en kombination av dessa fyra former för att legitimera eller rättfärdiga, men med betoning på kunskap och beprövad erfarenhet jämte professionsetik. Ofta är det inte helt lätt att avgöra vem som så att säga äger frågan för kontroll och ansvarsutkrävande, vilket visar att professionsresurser ofta ligger invävda i eller baseras på organisationsresurser.

\section{Fyra legitimitetsformer}

Politisk legitimitet skapas genom en öppen och fri debatt, där medborgare kan delta och där politikerna kan tillsättas och ställas till ansvar i fria demokratiska val. Byråkrati 
får sin legitimitet genom att politiskt beslutade, enhetliga och precisa lagar och regler tillämpas generellt av sakliga, opartiska och neutrala tjänstemän som kan ställas till ansvar i en hierarki. Professionell legitimitet baseras på kunskap och kompetens i sin tur baserad på kollegialt utvecklad och kontrollerad vetenskap och beprövad erfarenhet. Kompetensen kan vara erkänd av medborgare och staten, och i form av legitimation, auktorisation och skyddade yrkestitlar ger den monopol på en viss yrkesutövning. Marknad får sin legitimitet genom information om alternativa val, där individer fattar beslut under eget ansvar i en direkt bytesrelation mellan säljare och köpare, och där relationen mellan utbud och efterfrågan bestämmer pris på varan eller tjänsten. Byråkrati och profession kan ses som två former som inskränker marknader. Relationerna mellan dessa fyra legitimitetsformer är ständigt omdiskuterade, och det har skett betydande förskjutningar under senare år från politik till marknad, delvis på bekostnad av byråkrati och kollegial profession men samtidigt med större ansvar för enskilda professionella yrkesutövare. Detta kan sägas ha medfört en övergång från yrkesprofessionalism till organisatorisk professionalism.

\section{Fyra styrningsformer}

Förvaltningsstyrning är den styrning som politiker utövar med hjälp av lagar och förordningar. Med våra exempel rör det sig om hälso- och sjukvårdslagen jämte patientsäkerhetslagen, skollagen samt socialtjänstlagen. Lagarna implementeras och administreras i arbetsorganisationer genom organisationsstyrning av byråkrater och överordnade, där det tillkommer administrativa principer om vilka medel som bäst uppfyller målen jämte ekonomiska principer om måluppfyllelsens effektivitet samt specifika regler, föreskrifter och rutiner som kan vara starkt bundna till enskilda arbetsorganisationer och arbetsplatser. Lagar, myndighetsutövning och offentliga tjänster effektueras vidare ofta av professionella specialister som enligt lagar kan ha krav om vetenskap och beprövad erfarenhet, som i patientsäkerhetslagen, vilken bland annat reglerar yrkeskrav; eller resa sina särskilda giltighetsanspråk om vad som är sant och falskt, och vilka åtgärder som har visat sig effektiva - ofta i kombination med etiska regler om vad som är riktigt. Skollagen anger numera att: "Utbildningen ska vila på vetenskaplig grund och beprövad erfarenhet" (Sfs 2010:800, kap 1 §5). Den utgör ett exempel på att professionella krav om kunskap och etik kan övertas av politiska instanser och läggas in i lagtexter. Det är annars det typiska för professionsstyrning, där kollegiala organisationsformer främst baseras på utbildning, vetenskap och etik. Här är man antingen fokuserad på det kognitiva och på att lösa problem utifrån gemensamma sätt att förstå arbetets innehåll - objektfokuserad eller innehållsfokuserad styrning (Scott 2008:225). Därutöver finns marknadsstyrning genom efterfrågan på tjänster från allmänhet, medborgare eller klienter. Det har förekommit en klar tendens att rättsliga principer tonats ner, medan administrativa principer och ledarskap jämte effektivitet betonats starkare och fått större giltighetsanspråk. 
Det vill säga att förvaltningsstyrning minskat till fördel för organisationsstyrning - ibland i kombination med marknadsstyrning. (Tillspetsat är det en förändring från medborgerliga rättigheter till företags vinster.) Kommunallagen anger numera inga särskilda krav på personal i socialtjänsten, och Socialtjänstlagen anger bara "lämplig utbildning och erfarenhet". Den nya skollagen utgör däremot ett exempel på motsatsen med mycket starkare förvaltningsstyrning av läraryrket. Samtidigt har marknadsstyrningen gjort starka nedslag i skolpersonalens vardag som att konkurrera med andra skolor och kommuner, attrahera elever och föräldrar och i friskolors fall generera vinst (Lundström \& Parding 2011).

\section{Ansvar}

Begreppet ansvar är rent allmänt knutet till individers handlingar. Frihet att handla föreligger när vi kan välja olika alternativ, och vi har då ansvar för handlingarna och deras konsekvenser för andra och oss själva. Ju större handlingsutrymme man har i ett yrke, desto större ansvar följer därmed.

\section{Tabell I.}

Legitimitets- och styrformer.

\begin{tabular}{c|c}
$\begin{array}{c}\text { POLITIK } \\
\text { (fria val) } \\
\text { BESLUT }\end{array}$ & $\begin{array}{c}\text { BYRÅKRATI } \\
\text { (hierarki) } \\
\text { REGLER }\end{array}$ \\
\hline $\begin{array}{c}\text { PROFESSION } \\
\text { (kollegialitet) } \\
\text { KUNSKAP/ETIK }\end{array}$ & $\begin{array}{c}\text { MARKNAD } \\
\text { (fria val) } \\
\text { EFTERFRÅGAN }\end{array}$
\end{tabular}

Ansvar betyder att kunna ställa någon till svars eller att någon har skyldighet att stå till svars som fritt handlande subjekt. ${ }^{4}$ Sociala aktörer kännetecknas av att vara socialt responsiva i interaktioner med andra. Varje aktör förväntas också kunna ge skäl för sitt handlande. Mera specifikt kan ansvaret röra politiska, juridiska, ekonomiska och etiska förpliktelser. Det är en fråga om "att svara för sitt handlande och kunna påvisa att det står i överensstämmelse med socialt accepterade normer, antingen i en bredare betydelse eller $\mathrm{i}$ anslutning till gällande lagtext .../eller/ specifika professionella normer..." (Johansson 1998:46). Ansvar förutsätter ett subjekt som kan handla på andra sätt enligt egna bedömningar och därmed förhålla sig fri till plikter och normer i betydelsen att kunna handla annorlunda och därmed kunna göras ansvarig. Professionell diskretion är därmed mycket centralt i detta sammanhang. På engelska överlappar responsible (ansvarig) starkt med det mycket komplexa begreppet accountable (tillräknelig, ansvarig, redovisande). Det förra rör mer allmänna plikter, medan det senare oftare rör juridiskt, ekonomiskt och organisationsanknutet handlande. Som vi skall se nedan tenderar organisationsförändringarna att göra professionella mera redovisande (accountable) från att tidigare ha varit mer allmänt ansvariga (responsible).

Organisationers ansvar kan kort tecknas på följande sätt. Offentliga organisationers externa ansvar riktas mot och utkrävs av

4 Denna exkurs om begreppet ansvar följer mycket nära Johansson 1988:kap. 2. Se även Scott \& Lyman 1968; Bovens 2007. 
medborgare som väljare, skattebetalare och klienter. Det sker främst genom legal styrning och myndighetsutövning men också genom att offentliga tjänstemän är byråkratiskt underställda och ansvariga inför ledningen, som i sin tur är ansvarig inför politiker, som i sin tur utkrävs ansvar av medborgare i politiska val. Myndigheter och förvaltningar kan utkrävas ansvar av regeringen. Ansvar kan också utkrävas av klienter som klagan eller reklamationer via ombudsmän och klientorganisationer och statliga organ och domstolar. Internt ansvar handlar i offentlig sektor oftare om relationer till de professionella anställda och deras krav på autonomi och kollegialitet. Privata företags externa ansvar riktas mot kunder som köpare av varor och tjänster liksom mot konsument- och affärslagar. Privata företag har också ansvar gentemot leverantörer och aktieägare. Det interna ansvaret gentemot anställda har i många länder under långa tider varit avsevärt svagare i den privata sektorn jämförd med den offentliga. I skandinaviska länder har dock arbetslagstiftningen varit mera likvärdig för de båda sektorerna sedan 1970-talet.

\section{Utbildning}

Professionellt ansvar praktiseras på ett antal arenor. Det är för det första inom utbildning och urval av yrkesutövare, som är två starkt sammanbundna processer vilka utgör styrning in i såväl professioner som arbetsorganisationer. Antagning till utbildning jämte utbildningsformer och innehåll kontrolleras i viss grad av professionella yrkesorganisationer via statliga anordnare. Här kan professionen delvis medverka $i$ att stipulera krav i samband med legitimation och auktorisation. Därvid har Läkarförbundet varit klart mycket mera framgångsrikt än lärarnas och socionomernas förbund. Detta är en del av förvaltningsstyrningen, dvs. att styra genom att bestämma kraven på den personal som avses effektuera lagar, regler och tjänster. Den kan delvis vara delegerad till professionella organisationer. Utbildningen sker hos särskilda utbildningsanordnare som en slags standardisering av yrkesutövarna inför anställning, där det också sker en mera allmän sekundär socialisation in $\mathrm{i}$ yrkena och deras yrkeskulturer. Att denna urvals- och utbildningsprocess kontrolleras av yrket ifråga är en del i den klassiska professionella och kollegiala autonomin på organisationsnivå. Men i allmänhet har detta traditionellt varit svagare i skandinaviska och kontinentala länder jämförda med anglosaxiska. Professionsstyrning av utbildningen har dock delvis försvagats till förmån för organisationsstyrning och marknadsstyrning (Scott 2008; Muzio m. fl. 2011). Detta gäller dock knappast de tre här exemplifierade verksamheterna, och särskilt inte skolan och lärarna i och med skollagen från 2010. Urvalet in i många andra yrken i samband med rekrytering av personal har blivit mera avgörande och lämnar större ansvar hos arbetsgivaren och anställaren. Professionellas tillhörighet och identitet i förhållande till arbetsorganisationerna har i sådana fall blivit tydligare till nackdel för yrkestillhörighet och identitet knuten till de professionella yrkesförbunden (Östergren \& Sahlin-Andersson 1998; Noordegraaf 2011). 


\section{Arbetsorganisationer}

Professionellt ansvar praktiseras för det andra inom arbetsorganisationerna, där regler, lagar och föreskrifter utgör förvaltningsstyrningen av professionellas arbete. Enskilda offentliganställda yrkesutövare i en arbetsorganisation har ansvar i relation till tillsynsmyndighet, arbetsgivare, klient och allmänhet. I förvaltningslagen regleras t.ex. hur ärenden och beslut ska hanteras. Socialstyrelsen är tillsynsmyndighet över hälso- och sjukvården liksom över socialtjänsten och har dessutom sedan 2010 tagit över delar av länstyrelsernas tidigare tillsyn. Skolverket jämte statens skolinspektion utövar tillsyn över skolor. Hälso- och sjukvårdslagen, skollagen samt socialtjänstlagen är de främsta lagarna i detta sammanhang där läkares, lärares och socionomers samhällsuppdrag formuleras. Där anges ansvaret för olika anordnare liksom vilket ansvar enskilda yrkesutövare har.

Hälso- och sjukvårdslagen anger kraven för den verksamheten samt det ansvar som landsting och kommuner har. Föreskrifter om behörighet till tjänster får överlåtas på Socialstyrelsen. Patientsäkerhetslagen anger yrken med legitimation som skyddar yrkestitlarna och ger ensamrätt till att utöva yrkena på området. Kapitel 6 anger detaljerat skyldigheterna för personalen utöver att "utföra sitt arbete i överensstämmelse med vetenskap och beprövad erfarenhet". Var och en är också själv ansvarig för hur han eller hon fullgör sina arbetsuppgifter (Sfs 2010:659, kap 6, §1o2).

Skollagen anger alltså numera mycket detaljerat kraven på skolans lärare. För att få bedriva undervisning som anställd lärare och förskollärare med anställning utan tidsbegränsning ska man vara legitimerad (fr. 2015), och därmed har de ansvar för sin undervisning. Statens skolverk utfärdar legitimation som skyddar yrkestiteln om sökanden har behörighetsgivande examen, genomfört ett års introduktion och i övrigt befunnits lämplig att undervisa (Sfs 2010:800 kap. 2§13-16; Lilja 2011). Den myndighetsutövande betygssättningen jämte ansvar för kvaliteten i undervisningen är det centrala i kraven på legitimation. Införandet sker under fyra år från 2011, då lärare med fasta anställningar kan komplettera sin behörighet. Vissa lärargrupper är undantagna. Rektorer och förskolechefer ska genom utbildning och erfarenhet ha pedagogisk insikt.

Insatser inom socialtjänsten ska vara av god kvalitet. För utförande av uppgifter inom socialtjänsten ska det finnas personal med "lämplig utbildning och erfarenhet" (Sfs 2001:453, kap 3, §3). I övrigt anges inga specifika krav på personalen i socialtjänsten. Socionomer kan däremot ansöka om auktorisation efter tre års yrkesverksamhet genom förbundet Akademikerna SSR och Nämnden för socionomauktorisation. Men förbundet har också stående krav på statlig legitimation på sitt program (http://www. akademssr.se/professionalisering-i-tiden).

Vissa professionella yrkesutövare har en omfattande anmälningsplikt. Det gäller bland andra de tre yrken vi exemplifierar med här. Hälso- och sjukvårdspersonal ska bidra till hög patientsäkerhet genom att rapportera vårdskador och risker för sådana till vårdgivaren och Socialstyrelsen. Den som arbetar i vård eller omsorg har ansvar för att förhindra att fel leder till 
allvarliga konsekvenser för dem som får vård och behandling, eller får insatser från socialtjänsten. Ansvaret innefattar en skyldighet att rapportera s.k. avvikelser. Om en patient har fått en allvarlig skada eller riskerat att få en allvarlig skada i hälsooch sjukvården ska vårdgivaren anmäla händelsen till Socialstyrelsen enligt Lex Maria. När det gäller barn som far illa ska man samverka med berörda andra. Om en legitimerad yrkesutövares förskrivning av vissa läkemedel står i strid med vetenskap och beprövad erfarenhet ska den personal som expedierar anmäla detta till Socialstyrelsen. Den som arbetar med omsorg om äldre är enligt socialtjänstlagen skyldig att anmäla om någon utsätts eller har utsatts för allvarliga missförhållanden, såsom övergrepp eller vanvård enligt Lex Sarah. Samma skyldighet gäller för den som arbetar med omsorg av personer med funktionsnedsättning. Socialtjänstlagen anger vidare att var och en jämte myndigheter och anställda där är skyldig att anmäla kännedom om förhållanden där Socialnämnden ska ingripa för att skydda ett barn. Skolpersonal är enligt skollagen skyldig att till förskolechef eller rektor anmäla om ett barn eller en elev utsatts för kränkande behandling.

\section{Yrkesorganisationer}

Den tredje arenan består av yrkesorganisationer. Enskilda yrkesutövande medlemmar i en yrkesorganisation har skyldighet att följa de stadgar och de yrkesetiska regler som eventuellt ingår i medlemskapet. Att inte följa dem kan innebära anmärkningar eller i vissa fall uteslutning från förbundet. I Sverige är det dock bara i Advokatsamfundet, där uteslutning medför visst yrkesförbud (att uppträda som försvarare i domstol). Lagar och regler ligger ofta innehållsligt nära de etiska regler som utgör denna tredje arena och som kommer från professionella yrkesförbund och riktas till medlemmarna i förbunden och utgör en central del i den kollegiala organiseringen. (Från början handlade det om att reglera konkurrens och marknadsföring.) Så gott som varje professionellt förbund håller sig med etiska regler. Läkarförbundets hemsida anger att den som blir medlem i förbundet "ska följa de etiska reglerna och ska inte medverka $i$ sådan vård där man inte kan följa dem". ${ }^{5}$ De etiska reglerna sätter patienten i centrum och betonar läkares relationer till och bemötanden av patienten. Läkare "ska handla i enlighet med vetenskap och beprövad erfarenhet". Förbundets etik- och ansvarsråd handlägger yrkesetiska frågor och bevakar det som anknyter till läkarnas yrkesansvar. Lärarna har motsvarande etiska regler som sätter eleverna $\mathrm{i}$ centrum. Här betonas också läraryrkets professionella yrkesutövning, där man förbinder sig att "utveckla sitt arbete utifrån såväl vetenskap som beprövad pedagogisk erfarenhet". ${ }^{6}$ Lärarnas yrkesetiska råd (gemensamt för Lärarnas Riksförbund och Lärarförbundet) har en främjande, stödjande och rådgivande roll gentemot lärarkåren och ska medverka till att diskutera, utveckla och revidera

5 Sveriges läkarförbunds hemsida 2011-11-11

6 Lärarförbundets hemsida 2011-11-11, Lärares yrkesetiska principer 
principerna. ${ }^{7}$ Lärare förbinder sig att i sin yrkesutövning hålla principerna levande och aktivt ingripa mot sådant som strider mot dem. Socionomernas och SSR:s etiska regler anger, i ett mycket omfattande och reflekterande dokument, också att arbetet och yrkesrollen ska "relateras till vetenskap och beprövad erfarenhet". ${ }^{8}$ I övrigt rör reglerna främst relationer till klienter. Några punkter handlar dock om relationer till kollegor och till arbetsplatsen och verksamheten.

Denna professionsetik kan skiljas från, men samtidigt naturligtvis ha mycket gemensamt med, förvaltningsetik som finns i lagar och förordningar. En tredje form av etik är den personliga egenetiken, som $\mathrm{i}$ samband med professionella anspråk bör skiljas tydligt från de två andra. I samtliga tre fall ovan utgör de etiska reglerna en slags mjuka rekommendationer utan tydliga sanktioner, men är samtidigt mycket centrala i förbundens verksamhet. Hos samtliga finns regler om hur man ska förhålla sig till både patienter, elever respektive klienter och till kollegor. Men de omfattar inte någon anmälningsplikt, vilket istället regleras i lagar och handläggs av myndigheter enligt ovan.

Yrkesförbunds etiska regler kan också innehålla påbjudna relationer till kollegor. Läkarförbundets etiska regler anger att "Läkaren ska bemöta sina kollegor som han/hon vill bli bemött av dem. Utan att träda patientens intressen förnär ska läka-

7 Hemsidor för Lärarnas Riksförbund och Lärarförbundet 2011-11-11

8 Akademikerna SSR:s hemsida 2011-11-11,Etik i socialt arbete $\mathrm{s} 14$ ren respektera sina kollegors arbete och så långt det är möjligt undvika att undergräva kollegors relationer till patienten." ${ }^{9}$ Lärare ska visa god kollegialitet men inte på ett sådant sätt att det kan leda till en handling eller underlåtenhet som kan skada eleverna. Lärare ska ingripa om en kollega uppträder kränkande mot en elev eller motverkar en elevs rättigheter. ${ }^{10}$ Socialarbetare bör visa lojalitet och respekt för kollegor och andra medarbetare i olika befattningar. De ska motverka kränkande eller diskriminerande attityder och handlingar som kan komma till uttryck i verksamheten eller hos medarbetare eller klienter. ${ }^{11}$

Sådan intern professionell, kollegial kontroll blir effektivare när arbetet organiseras och utförs i arbetslag, vilket är vanligt i hälso- och sjukvård liksom socialt arbete, men är ett ganska nytt inslag i skolan. Här har det kollegiala samarbetet mycket stora fördelar. Det kan vara nära kopplat till ledningskontroll som i många arbetsorganisationer med projektgrupper och team. Där finns rikliga tillfällen till formell och informell kontroll av arbetet och av relationerna till patienter, klienter och elever under arbetets gång.

En annan typ av intern kontroll som ligger nära eller kan sammanfalla med anmälningsskyldigheter och etiska principer att bevaka arbetet och klienters behandling och välfärd, utgör enskilda yrkesutövares alarm vid särskilda händel-

9 Läkarförbundets etiska regler punkt 15

10 Lärarförbundets och Lärarnas Riksförbunds etiska regler 2011

11 Etisk kod för socialarbetare, SSR 2011 punkt 13 o 14 
ser (Lundquist 2001:233ff; McConnell 2005). De kallas visslare, varslare eller viskare (whistleblower) och har i vissa länder särskilt lagskydd. Friheten att anmäla händelser som misstänks skada enskilda eller allmänhet varierar mycket mellan olika arbetsplatser, organisationer och professioner. Så kallad meddelarfrihet kompletterad med meddelarskydd i offentlig verksamhet innebär dock en allmän rätt att anonymt lämna uppgifter till medier som omfattas av yttrandefrihetsgrundlagen. Privata organisationer omfattas inte av meddelarskyddet, vilket f.n. är omdiskuterat.

\section{Klientmöten}

En fjärde arena rör de direkta mötena med mottagarna eller patienter, elever och klienter. Professionellas relationer till mottagare av tjänster är i detta sammanhang av den medierade typen, där staten som tredje part fastställer mycket av både behoven och hur de ska tillfredsställas till skillnad från den klientkontrollerade relationen respektive den kollegialt kontrollerade (Johnson 1972). (I mer marknadsliknande sammanhang upprättas istället en kundrelation.) Läkarnas, lärarnas och socialarbetarnas mest effektiva och omedelbara kontrollanter är mottagarna av tjänsterna: patienter, elever respektive klienter. De har genom lagstiftningar getts större inflytande och makt att medverka i planering av insatser. Detsamma gäller anmälningsmöjligheter, som också kan vara understödda av patientorganisationer, elevorganisationer respektive klientorganisationer eller andra intresseorganisationer. Från 2011 gäller ett nytt system för anmälningar mot hälso- och sjukvårdspersonal. Hälso- och sjukvårdens ansvarsnämnd (HSAN) hanterar nu frågor om prövotid, indragning av förskrivningsrätt och återkallelse av legitimation efter anmälan från Socialstyrelsen. Patienter och närstående som vill anmäla hälso- och sjukvårdspersonal ska lämna in anmälan till Socialstyrelsen, som därefter gör en utredning och fattar beslut, där kritik kan riktas mot vårdgivaren eller hälso- och sjukvårdspersonalen. Legitimerade lärare ska kunna anmälas till Skolinspektionen som avgör om ärendet ska gå vidare till Lärarnas ansvarsnämnd, vilken beslutar om åtgärd att utfärda varning eller återkalla lärares legitimation. Enligt socialtjäntslagen har klienter rätt att till allmän förvaltningsdomstol överklaga beslut.

Klienter av olika slag har också en mer informell kontroll, när de medverkar under samtycke till tjänsterna. Enskilda klienter i enrum utgör en effektiv kontroll. Ännu effektivare kan ett kollektiv som en skolklass vara för att kontrollera lärares arbete. Interaktionen i klassrummet utspelas inför denna offentlighet som på en teaterscen, vilket gör arbetet samtidigt ofantligt mycket mera komplicerat, oförutsägbart och kontrollerbart än om man möts på tu man hand i ett mottagnings- eller behandlingsrum. Lärarna måste arbeta hårt på att kontrollera händelseförloppen i klassrummet och balansera mellan att möta eleverna som individer och som kollektiv.

Klientkontrollen så långt har handlat om att kunna delta, samtycka och uttrycka sig eller ge röst åt sina behov och önskemål. Det nya ledarskapet har däremot oftare rört sig om att ge patienter, elever och klien- 
ter möjligheter att rösta med fötterna, dvs. kunna välja vem man vill anlita för en viss tjänst. Det handlar då om att införa marknadsliknande relationer som visar efterfrågan. Medborgarna skall kunna informera sig om vilka olika vårdgivare och undervisningsanordnare som finns och vilken kvalitet tjänsterna har till vilket pris. Detta ses som ett sätt att möta byråkratisk rigiditet och professionell paternalism. En rad reformer i den riktningen har gjorts inom såväl hälso- och sjukvård som skola och socialtjänst. Det finns numera kvalitetsmått på tjänster att tillgå för allmänheten i många verksamheter (Bejerot \& Erlingsdotter 2002; Hasselbladh m. fl. 2008; Foss Lindblad \& Lander 2009; Sandell 2009).

\section{Kvalitetsstyrning}

En femte arena och en relativt ny praktik gäller just sådan kvalitetskontroll eller kvalitetsstyrning som förr ofta gick under den gemensamma beteckningen Total Quality Management (TQM). Den hör nära ihop med arbetsorganisationerna, och den kan ses som ett försök att omdefiniera och fastställa verksamhetens mål, att skapa legitimitet i organisationen och att arbeta med metoder "för att mäta, utvärdera och förändra verksamheten med kundtillfredsställelse som ledstjärna" (Bejerot \& Hasselbladh 2002:9; även Hasselbladh m. fl. 2008; Blom m. fl. red. 2011). Marknaden flyttas så att säga in i arbetsorganisationen med de kunder som konstrueras av ledningen genom återkopplingar och utvärderingar, och kundernas preferenser blir en del av ledningen och styrningen av de profes- sionella yrkesutövarna. Den omfattar olika utvärderingar och uppföljningsmetoder för att, både från ledningen och från klienterna eller deras representanter i klientorganisationer, kontrollera utförandet av professionellas arbete. Professionellas expertis tas där inte för given utan sätts under ständig lupp, vilket utgör en kontroll av pågående arbete och av resultaten i efterhand som därmed ersätter eller kompletterar kontroll i förväg bestående av standardiserad utbildning, och där utbildning och kompetens bara är en indikator bland många andra. Medborgarna som konsumenter och deras rättigheter avses få företräde. ${ }^{12}$ Metoderna bryter starkt mot kollegial kontroll och professionell organisering och utgör en väsentlig del i diskursen för organisatorisk professionalism eller arbetsorganisationernas auktoritet och legitimitet (Evetts 2010; Muzio m. fl. 2011). De s.k. öppna jämförelserna inom hälso- och sjukvården är en utveckling av kvalitetsregistren och erbjuder nationella jämförelser tillgängliga för andra än den professionella personalen. De har inneburit standardisering och byråkratisering med starkare kontroll inom arbetsorganisationerna jämte större tillgänglighet för såväl lekmän i styrelser och ledningar som patienter (Blomgren \& Waks 2011).

I detta sammanhang är det väsentligt att kort behandla vad som kallas evidensbaserat arbete och som återverkar på etik och kollegiala relationer (Grimen \& Terum

\footnotetext{
12 Utvärdering kan också förekomma inte bara i efterhand utan även före som planering, policy, behovsanalys och bedömningsinstrument, och under i form av processutvärdering gärna med lärande inslag (Denvall 2011:39ff.).
} 
2009; Liljegren \& Parding 2010; Blom m. fl. red. 2011; Bergmark \& Lundström 2011). Det går ut på att sammanställa forskning inom ett område som underlag för verksamma åtgärder och professionell intervention. Syftet med evidensbaserad medicin är att minska avståndet mellan forskning och praktik genom att ha större dokumentation av behandlingseffekter som kan tillämpas mera direkt i den kliniska verksamheten (Ekeland 2009; Oscarsson 2011). Evidensbasering är en del i en ny kodifiering och styrning som från slutet av 1980-talet har utvecklats och spridits mycket snabbt inom en rad medicinska specialiteter och på andra vårdområden liksom inom socialt arbete. Den anger ett antal kriterier för studier och för att de skall sägas uppnå metodologisk s.k. guldstandard eller gyllene standard. Den formuleras i behandlingsmanualer, mönster och modeller. Härigenom avser man att minska diskretionen i arbetet och införa starkare samtidig kontroll. Det sker en utveckling från kollektiva lösningar till individuella som på området socialt arbete delvis handlar om medikalisering (Oscarsson 2011:184 ff.). Kritiker har anfört att metodkraven tenderar att favorisera vissa diagnoser och behandlingstyper (Ekeland 2009), eller att programmet helt enkelt lovar för mycket (Bergmark \& Lundström 2011:181). Etik och kollegialitet och de former av ansvar och ansvarsutkrävande som följer med sådan organisering utmanas således på flera nya sätt, vilket gör att professionella yrkesgrupper tvingas att omförhandla och förnya sin etik och sina kollegiala relationer. Det syns i flitigare hänvisningar till etik i professionella praktiker i samband med konkreta fall, men särskilt vad gäller ekonomiska och politiska beslut som snarare rör etik på institutionell nivå (Freidson 2001:216ff; Hasselbladh m. fl. 2008; Egidius 2011).

\section{Avslutande kommentarer}

Artikeln söker sätta in professionella yrkesutövare och deras arbete i organisatoriska sammanhang genom en uppsättning begrepp som rör kontroll, styrning och ansvar. Professionellas beslut kan i princip legitimeras med förvaltningsregler i kombination med yrkesetiska regler och värden som man har att lyda eller rätta sig efter, eller det mest typiska i professionellt arbete, med hjälp av kunskap och beprövad erfarenhet i ett kollegialt sammanhang, och där också ofta med professionsetisk hänsyn. Till det kan ibland, och allt oftare, läggas efterfrågan på en marknad. Beslut om åtgärder i professionellt arbete utgör därför ofta en kombination av dessa fyra former för att legitimera eller rättfärdiga, men med betoning på kunskap och beprövad erfarenhet jämte professionsetik. Styrning kan uppträda i fyra analytiska former: förvaltnings-, organisations-, professionsoch marknadsmässig styrning. Professionellas ansvar är mer eller mindre knutet till dessa legitimitets- och styrningsformer. Det praktiseras på ett antal arenor: utbildning, yrkesorganisationer, arbetsorganisationer, i relationer till klienter eller motsvarande mottagare samt i form av kvalitetsstyrning.

Kontroll och styrformer i professionellt arbete har i denna artikel exemplifierats med sjukvård, skola och socialtjänst. 
Under senare decennier har stora förändringar inom dessa verksamheter förekommit. Avreglering, målstyrning och ramlagar har försvagat förvaltningsstyrning till förmån för vissa marknadsliknande och kundinriktade former för valfrihet samt organisationsstyrning $i$ arbetsorganisationer och deras ledningar att sätta mål och att bestämma åtgärder och att mäta effektivitet. Samtidigt har nya former av resultatstyrning införts och delegerats ibland ner till enskilda arbetsgrupper och yrkesutövare. Det kan gälla arbetslag sammansatta av liknande eller näraliggande professionella yrkesgrupper, där arbetsorganisationen därmed överlämnar ansvaret för tjänsteproduktionens effektivitet till professionella grupper och yrkesutövare. Det har skett i stor omfattning med hjälp av metoder för att säkra kvaliteten i tjänsterna som i sin tur hör ihop med metoder för att utvärdera verksamheten och resultaten, och där patienter, elever och klienter och deras organisationer samt allmänhet getts större utrymme att kontrollera.

Kollektiv kollegial professionell styrning och ansvar för både utförande och val av professionella tjänster har därmed tenderat att minska, medan individuell professionell styrning och ansvar har ökat. Rätten att utkräva ansvar har förskjutits från kollektiv politik jämte professionell kollegialitet baserad på kunskap och etik till organisationsledningars effektivitet och mottagarnas behovstillfredsställelse. I den utsträckning utvärderingar kontrolleras av externa aktörer har också därigenom skett en förskjutning av kontrollen bort från intern kollegial kontroll och därmed också den etik som professionella är bärare av genom att tillhöra sådana professionella organisationer som Läkarförbundet, lärarförbunden eller Socionomförbundet. Samtidigt tenderar den professionella praktikens komplicerade bedömningar i arbetslag och hos enskilda yrkesutövare under diskretion att delvis bytas mot fler inslag av evidensbaserade paketlösningar, mallar, manualer och system som styr och kontrollerar arbetet under tiden det pågår. Styrning med regler och utbildning som standardisering i förväg avlöses därmed av starkare kontroll av arbetets utförande medan det pågår, liksom dess resultat i efterhand. De senaste decennierna har inneburit förändringar som påverkar relationerna mellan aktörer och kontroll av professionellt arbete och var och i vilken form ansvar för detta arbete kan utkrävas. Professionella tenderar därmed att mer direkt behöva redovisa sina resultat för arbetsgivare och klienter än att vara kollegialt ansvariga utifrån sina kunskaper och sin etik. Man kan kalla det för en övergång från ansvar (responsibility) till redovisning (accountability) - eller mer allmänt granskning. Såväl sjukvård, skola som socialt arbete ingår numera i vad som med Michael Power kan kallas granskningssamhället, där dokumentation, transparens och kontroll genomsyrar så gott som allt professionellt arbete och har blivit den främsta metoden för legitimitet (Power 1997:147; Nygren \& Hanberger 2011:300).

Det ligger då nära till hands att med Elliot Freidson instämma $i$ att rofessionalismen som ett sätt att kontrollera viss yrkesverksamhet och därigenom skapa legitimitet åter har utmanats starkt av den fria marknadens logik och av det rationella ledarskapets logik (Freidson 2001). Effek- 
tivitet, ledningskontroll och valfrihet har satts framför rättvisa som legitimitetsgrunder, och detta har föranlett en rad kritiska analyser av offentliga professionella tjänster. $^{13}$ Marknadens individuella valfrihet och mikroekonomins preferenser framträder som starkare grunder för legitimitet än politiska beslut om rättigheter utifrån politiskt grundade värderingar. De professionella samhällsuppdragen förvaltas och genomförs främst i professionella byråkratiska arbetsorganisationer som har genomgått betydande förändringar internt och $\mathrm{i}$ relation till sina omgivningar. Politisk styrning och förvaltningsstyrning har tenderat att minska, medan organisationsstyrning och organisationsledning med kvalitetsoch marknadsmetoder har ökat. Utvärderingar har blivit mycket framträdande i de närmare och mera kundliknande relationerna till patienter, elever och klienter. Ökad kunskap och större valfrihet hos brukare i kombination med utvärderingar och

13 Eriksen 1997, 2001; Lundquist 2001; Considine 2001; Dent \& Whitehead red. 2001; Busch m.fl. red. 2005; Blomqvist \& Rothstein 2001; Hasselbladh m fl 2008; Hartman red. 2011. resultatkontroll, har också gett närmare relationer till patienter, elever, föräldrar och klienter och deras värderingar. Omgivningen och externa aktörer har därmed fått större inflytande både genom efterfrågan av tjänster och genom utvärderingar av resultat.

Utvärderingar har således en tendens att flytta fokus från professionell kunskap och etik till resultat och nya typer av regler i form av standardiserade procedurer och rutiner. Detta får konsekvenser för självständiga bedömningar av fall inom professionellt definierad och kollegialt utövad kunskap. Dessa yttre kontrollformer utmanar och omförhandlar också det politiskt formulerade samhällsuppdraget och den professionellt formulerade etiken. Marknadsstyrning med kvalitetssäkring och klient(kund)kontroll har byggts in $i$ organisationsstyrningen. Professionella och anställda knyts därmed närmare arbetsorganisationernas auktoritet, effektivitet och kontext i denna nya s.k. organisatoriska professionalism, som här har visats med exempel från sjukvården, skolan och socialtjänsten. 


\section{Referenser}

Bejerot, Eva \& Hasselbladh, Hans (2002) Kvalitet utan gränser. En kritisk belysning av kvalitetsstyrning. Lund: Academia Adacta.

Bejerot, Eva \& Erlingsdotter, Gudbjörg (2002) Kvalitetsidéns materialisering $\mathrm{i}$ hälso- och sjukvården, i Bejerot \& Hasselbladh red. ss. 59-81.

Bergmark, Anders \& Lundström, Tommy (2011) Evidensbaserad praktik i svenskt socialt arbete: Om ett programs mottagande, förändring och möjligheter i en ny omgivning. I Bohlin \& Sager red. ss. 163-184.

Blom, Björn; Morén, Stefan \& Nygren Lennart (red.) (2011) Utvärdering $i$ socialt arbete: Utgångspunkter, modeller och användning. Sthlm: Natur \& Kultur.

Blomgren, Maria \& Waks, Caroline (2011) Öppna jämförelser inom hälso- och sjukvården - en utmaning mot den professionella byråkratin? Arbetsmarknad \& Arbetsliv, årg 17, nr 4, ss. 95-108.

Blomqvist, Paula \& Rothstein, Bo (2001) Välfärdsstatens nya ansikte. Demokrati och marknadsreformer inom den offentliga sektorn. Stockholm: Agora.

Bohlin, Ingemar \& Sager, Morten (red.) (2011) Evidensens många ansikten: Evidensbaserad praktik i praktiken. Lund: Arkiv.

Bourgeault, Ivy Lynn; Hirschkorn, Kristine \& Sainsaulieu, Ivan (2011) Relations between professions and organizations: More fylly considering the role of the client. Professions \& Professionalism, volym 1, nr 1, ss. 67-86.

Bovens, Mark (2007) Analysing and assessing accountability: A conceptual framework. European Law Journal, Vol. 13:4 July, ss. 447-468.

Busch, Tor; Johnsen, Erik; Klausen Kurt, K \& Vanebo, Jan, O (red.) (2005 andra uppl) Modernisering av offentlig sektor. Utfordringer, metoder og dilemmaer. Oslo: Universitetsforlaget.

Child, John (2005) Organization. Contemporary Principles and Practice. Oxford: Blackwell.

Considine, Mark (2001) Enterprising States. The public management of welfare-to-work. Cambridge: University Press.
Dent, Mike \& Whitehead, Stephen (red.) (2002) Managing Professional Identities: knowledge, performativity and the 'new' professional. London: Routledge.

Denvall, Verner (2011) Det sociala utvärderingslandskapet. I Blom m. fl. red. ss. 37-54.

Egidius, Henry (2011) Etik och profession: I en tid av ökande privatisering och myndighetskontroll. Lund: Studentlitteratur.

Ekeland, Tor-Johan (2009) Hva er evidensen for evidensbasert praksis? I Grimen \& Terum (red.) ss. 145-168.

Eriksen, E.O. \& Molander, A. Profesjon, rett og politikk. I Molander \& Terum red. 2008, ss. 161-175.

Eriksen, Erik Oddvar (1997) Kommunikativt ledarskap. Om styrning av offentliga institutioner. Göteborg: Daidalos.

Eriksen, Erik Oddvar (2001) Demokratiets sorte hull: om spenningen mellom fag og politikk i velferdsstaten. Oslo: Abstrakt.

Etik $i$ socialt arbete. Etisk kod för socialarbetare. Sthlm: Akademikerförbundet SSR 2011.

Evetts, Julia (2006) Organizational and occupational professionalism: the challenge of new public management paper XVI, ISA World Congress of Sociology, Durban.

Freidson, Elliot (2001) Professionalism. The third logic. Oxford: Polity Press.

Foss Lindblad, Rita \& Lander, Rolf (red.) (2009) Att säkra det osäkra: Reflektion och makt $i$ skolans utvärdering. Lund: Studentlitteratur.

Grimen, Harald (2008) Profesjon og profesjonsmoral. I Molander \& Terum red. ss 144-159.

Grimen, Harald \& Terum, Lars Inge (red.) (2010) Evidensbasert profesjonsutövelse. Oslo: Abstrakt förlag.

Hall, Richard (1968) Professionalization and Bureaucratization. American Sociological Review, Volym $33 \mathrm{nr} 1$ (febr), ss. 92-104.

Hargreaves, Andy (1994) Changing Teachers, Changing Times: Teacher's Work and Culture in the Postmodern Age. London: Cassell.

Hartman, Laura (red.) (2011) Konkurrensens kon-

Lennart G Svensson: Profession, organisation, kollegialitet och ansvar. 
sekvenser: Vad händer med svensk välfärd? Sthlm: SNS förlag.

Hasselbladh, Hans, Bejerot, Eva \& Gustafsson, Rolf (red.) (2008) Bortom New Public Management: Institutionell transformation I svensk sjukvård. Lund: Academia Adacta.

Johansson, Roine (1992) Vid byråkratins gränser. Om handlingsfrihetens organisatoriska begränsingar $i$ klientrelaterat arbete. Lund: Arkiv.

Johansson, Ulla (1998) Ansvarsföreställningar och deras betydelse för den organisatoriska verkligheten. Lund Studies in Economics and Management 43.

Johnson, Terrance (1972) Professions and power. London: The Macmillan Press Ltd.

Larsson, Håkan \& Morén, Stefan (1988) Organisationens mänskliga insida. Om det sociala arbetets utvecklingsmöjligheter. Studier i socialt arbete volym 7 , Umeå universitet.

Lazega, Emmanuel. (2001) The Collegial Phenomenon. The social mechanisms of cooperation among peers in a corporative law partnership. Oxford: Oxford University Press.

Lilja, Peter (2011) Lärarlegitimation - professionalisering med förhinder? Arbetsmarknad \& Arbetsliv, årg 17 nr 4, ss. 29-42.

Liljegren, Andreas \& Parding, Karolina (2010). Ändrad styrning av välfärdsprofessionerexemplet evidensbasering i socialt arbete. Socialvetenskaplig tidskrift, 17(3-4), ss. 270-288.

Lundström, Ulf \& Parding, Karolina (2011) Lärares upplevelser av friskolereformen - effekter av marknadiseringen av den svenska gymnasieskolan. Arbetsmarknad \& Arbetsliv, årg 17, nr 4, ss. 59-78.

Lundquist, Lennart (2001) Med borgardemokratin och eliterna. Lund: Studentlitteratur.

McConnell, Terrance (2005) Whistle-blowing i Frey, R.G. \& Wellman, C.H. red. A Companion to Applied Ethics, Blackwell Publ.

Mintzberg, Henry (1983) Structure in Fives. Prentice Hall, New Jersey.

Molander, A \& Terum L-I. (red. 2008) Profesjonsstudier, Oslo: Universitetsforlaget.

Muzio, Daniel \& Kirkpatrick, Ian (2011) Introduc- tion: Professions and organizations - a conceptual framework. Current Sociology volym 59:4, ss. 389-405.

Muzio, Daniel m. fl. (2011) Towards corporate professionalization: The case of project management, management consultancy and executive search. Current Sociology, volym 59:4, ss. 443-464.

Noordegraaf, Mirko (2011) Risky Business: How professionals and professional fields (must) deal with organizational issues. Organization Studies, volym $32 \mathrm{nr}$ 10, ss. 1349-1371.

Nygren, Lennart \& Hanberger, Anders (2011) Socialt arbete i granskningssamhället. I Blom m. fl. (red.) Utvärdering $i$ socialt arbete: Utgångspunkter, modeller och användning. Stockholm: Natur och Kultur, ss. 300-314.

Oscarsson, Lars (2011) Utvärdering och evidensbasering. I Blom m. fl. (red.) ss. 183-198.

Power, Michael (1997) The Audit Society: Rituals of verification. Oxford University Press.

Sandell, Göran (2009) Integrerad utvärdering av välfärdens nytta i brukarnas liv: Värdegrund, teori, metod och IT-stöd för dialog, evidens och kvalitet. Inst. för socialt arbete, Göteborgs universitet.

Scott, Marvin B \& Lyman, Stanford M (1968) Accounts. American Sociological Review, volym $33 \mathrm{nr} 1$ (febr) ss. 46-62.

Scott, W. Richard [1981](2003) Organizations. Rational, Natural, and Open Systems. New Yersey: Prentice Hall.

Scott, W. Richard (2008) Lords of the dance: Professionals as institutional agents. Organization Studies, volym $29 \mathrm{nr}$ 2, ss. 219-238.

Svensk författningssamling 2001:453; 2010:659; 2010:800.

Svensson, Lennart G (2008) Profesjon og organisasjon. I Molander \& Terum red.

Vedung, Evert (2011) Några traditionella utvärderingsmodeller. I Blom m. fl. (red.) Utvärdering $i$ socialt arbete: Utgaingspunkter, modeller och användning. Stockholm: Natur och Kultur, ss103-121.

Waters, Malcolm. (1989) Collegiality, bureaucratization, and professionalization: A Weberian 
analysis, American Journal of Sociology, Volym

94:5, March, ss. 945-72.

Wilensky, Harold L. (1964) The Professionalization of Everyone. The American Journal of Sociology, Volym 70, nr 2 (sept), ss. 173-158.
Östergren, Katarina \& Sahlin-Andersson, Kerstin (1998) Att hantera skilda världar. Läkares chefskap i mötet mellan profession, politik och administration. Stockholm: Landstingsförbundet.

\section{Summary}

\section{Profession, organisation, collegiality and responsibility}

Professions execute a certain type of knowledge in a collegial form of organization with some kind of political legitimacy to implement and perform a certain public mission. The certain knowledge and the collegial organization are the bases of professional work, and are separated from bureaucratic rules and the demand at the market, where managers and consumers, respectively, rather than professionals in relation to clients execute control.

The objective of this paper is to analyse different forms of control, legitimacy, and accountability with some illustrations from the health service, education and social work. In particular, the paper deals with challenges and contradictions between collegiality and bureaucracy and between occupational professionalism and organizational professionalism, i.e. professionalism in relation to the collegiality of professional associations and rational-legal authority in work organizations.

The privilege to execute accounting has in recent decades been altered from collective politics and professional collegiality based on knowledge and ethics into the efficiency of organizational management and to the satisfaction of needs of consumers at the market. Governing and controlling by knowledge and education as well as bureaucratic rules as two kinds of standardization beforehand, have partly been challenged by control of the performance of in-servicework afterwards - a trend from responsibility into accountability. 